\title{
Debris-flow modeling at Meretschibach and Bondasca catchments, Switzerland: sensitivity testing of field-data-based entrainment model
}

\author{
Florian Frank $^{1}$, Brian W. McArdell ${ }^{1}$, Nicole Oggier ${ }^{2}$ Patrick Baer $^{3}$, Marc Christen $^{4}$, and Andreas Vieli ${ }^{3}$ \\ ${ }^{1}$ Swiss Federal Institute for Forest, Snow and Landscape Research, Birmensdorf, 8903, Switzerland \\ ${ }^{2}$ wasser/schnee/lawinen, Ingenieurbüro André Burkard AG, Brig-Glis, 3900, Switzerland \\ ${ }^{3}$ Glaciology, Geomorphodynamics \& Geochronology, Department of Geography, University of Zurich, \\ Zurich, 8057, Switzerland \\ ${ }^{4}$ WSL Institute for Snow and Avalanche Research SLF, Davos Dorf, 7260, Switzerland \\ Correspondence to: Florian Frank (florian.frank@wsl.ch)
}

Received: 6 September 2016 - Discussion started: 30 September 2016

Revised: 30 March 2017 - Accepted: 22 April 2017 - Published: 1 June 2017

\begin{abstract}
Debris-flow volumes can increase due to the incorporation of sediment into the flow as a consequence of channel-bed erosion along the flow path. This study describes a sensitivity analysis of the recently introduced RAMMS (Rapid Mass Movements) debris-flow entrainment model, which is intended to help solve problems related to predicting the runout of debris flows. The entrainment algorithm predicts the depth and rate of erosion as a function of basal shear stress based on an analysis of erosion measurements at the Illgraben catchment, Switzerland (Frank et al., 2015). Starting with a landslide-type initiation in the RAMMS model, the volume of entrained sediment was calculated for recent well-documented debris-flow events at the Bondasca and the Meretschibach catchments, Switzerland. The sensitivity to the initial landslide volume was investigated by systematically varying the initial landslide volume and comparing the resulting debris-flow volume with estimates from the field sites. In both cases, the friction coefficients in the RAMMS runout model were calibrated using the model, whereby the entrainment module was (1) inactivated to find plausible values for general flow properties by adjusting both coefficients ( $\xi$ and $\mu$ ) and then (2) activated to further refine coefficient $\mu$, which controls erosion (patterns). The results indicate that the model predicts plausible erosion volumes in comparison with field data. By including bulking due to entrainment in runout models, more realistic runout patterns are predicted in comparison to starting the model with the entire debris-flow volume (initial landslide
\end{abstract}

plus entrained sediment). In particular, lateral bank overflow - not observed during these events - is prevented when using the sediment entrainment model, even in very steep $(\approx 60$ $65 \%)$ and narrow (4-6m) torrent channels. Predicted sediment entrainment volumes are sensitive to the initial landslide volume, suggesting that the model may be useful for both reconstruction of historical events and the modeling of scenarios as part of a hazard analysis.

\section{Introduction}

Sediment erosion caused by debris flows causes flow bulking (in our case an increase in flow mass; e.g., Iverson, 1997), which strongly influences the runout behavior of debris flows. The term erosion can be defined as the process of removing sediment from the channel bed, while sediment entrainment describes the procedure of incorporating the eroded sediment into the debris flow. The entrainment of eroded sediment along the channel has been observed to considerably increase the volume of debris flows (i.e., bulking process) at many different locations (e.g., Hungr et al., 2005; Scheuner et al., 2009; Iverson et al., 2011; Berger et al., 2010a, 2011; Schürch et al., 2011; McCoy et al., 2012; Tobler et al., 2014; Frank et al., 2015). Two recent extreme examples from the central Swiss Alps in the last decade showed significant bulking along the flow path. In the Spreit- 
graben catchment (2009-2011), the overall multi-surge event volumes increased to about 90000 to $130000 \mathrm{~m}^{3}$ - mainly due to entrainment along the active channel on the fan (Tobler et al., 2014; Frank et al., 2015). At the Rotlauigraben catchment (2005), about two-thirds of the total volume of $550000 \mathrm{~m}^{3}$ was eroded from the debris-flow fan during a multiple-surge debris-flow event initiated by the failure of a glacier moraine during an intense rainfall event (Scheuner et al., 2009). Therefore, the debris-flow entrainment and bulking process should be included in debris-flow runout models to increase the accuracy of runout predictions including not only the overall runout distance, location, and amplitude of lateral bank overflow but also - importantly for hazard assessment - the flow and depositional pattern on the fan (Gamma, 2000; Scheuner et al., 2009; Hussin et al., 2012; Han et al., 2015; Frank et al., 2015).

However, models which include bulking by debris flows are relatively new, and their performance for practical applications has not yet been systematically investigated. Most entrainment modeling studies have focused on the field site where the erosion data for the underlying entrainment modeling concept was collected and/or exclusively dealt with a single model application field site to test their concept for entrainment modeling (e.g., Han et al., 2015; Frank et al., 2015). Herein we describe the systematic application of the new RAMMS (Rapid Mass Movements) entrainmentbulking model (Frank et al., 2015) for several recent events in the Swiss Alps.

Computational debris-flow runout models, which usually neglect entrainment, are often used to assess runout distance and pattern (Crosta et al., 2003; D'Ambrosio et al., 2003; Medina et al., 2008; Hungr and McDougall, 2009; Christen et al., 2012) and are therefore useful for hazard analysis where predictions of flow intensity (e.g., the spatial distribution of flow depth and velocity) are required (e.g., Scheuner et al., 2011). Because the debris-flow process has often been observed to cause significant entrainment of sediment, which can strongly influence the flow (e.g., Dietrich and Dunne, 1978; Suwa and Okuda, 1980; Gallino and Pierson, 1984; Hungr et al., 1984; Benda, 1990; Pierson et al., 1990; Meyer and Wells, 1997; Vallance and Scott, 1997; Berti et al., 1999; Cannon and Reneau, 2000; Fannin and Wise, 2001; May, 2002; Wang et al., 2003; Revellino et al., 2004; Scott et al., 2005; Godt and Coe, 2007; Breien et al., 2008; Gartner et al., 2008; Pastor et al., 2009; Guthrie et al., 2010; Procter et al., 2010; Berger et al., 2010a, b, 2011; Schürch et al., 2011; Iverson et al., 2011; McCoy et al., 2012; Cascini et al., 2014; Tobler et al., 2014; Frank et al., 2015), including entrainment and bulking debris-flow runout modeling would be appropriate. Processed-based entrainment rates using algorithms which consider the material properties of the debrisflow bulk (Crosta et al., 2003; D'Ambrosio et al., 2003; Medina et al., 2008; Deubelbeiss and McArdell, 2012) as well as pre-specified entrainment rates which pre-define the absolute volume of eroded material (Beguería et al., 2009; Hungr and
McDougall, 2009; Hussin et al., 2012) have been introduced in numerical runout models.

Recently, we introduced an entrainment algorithm in the RAMMS debris-flow model for the assessment of debrisflow entrainment and bulking (Frank et al., 2015). The entrainment algorithm uses a relation between basal shear stress and erosion depth based on an analysis of data from the Illgraben catchment, Switzerland (Frank et al., 2015; Berger et al., 2011; Schürch et al., 2011). The entrainment model was used to predict the overall erosion pattern and erosion volume at the first site where it was tested, the Spreitgraben, Switzerland. However, secondary erosion processes such as bank collapse and small torrential flood events between the debris-flow events increased the uncertainty in the evaluation of the model. As a consequence, additional sensitivity tests were not carried out. In this study we therefore focus on testing the sensitivity of the RAMMS debris-flow and entrainment model by assessing the sensitivity of total event volume (initial landslide volume plus volume of eroded sediment) to initial flow volume. This is especially important in hazard analysis where landslide scenarios are considered to trigger debris flows. For this sensitivity analysis, we evaluated two Alpine catchments with diverse topography and recent well-documented debris flows with volumes up to a few $10000 \mathrm{~m}^{3}$ : the Bondasca catchment in southeastern Switzerland and the Meretschibach catchment in southern Switzerland.

\section{Entrainment modeling study sites and available data}

\subsection{Meretschibach catchment, Switzerland}

The Meretschibach catchment is located in southern Switzerland, adjacent to and east of the Illgraben catchment (Fig. 1). The catchment area is about $9.2 \mathrm{~km}^{2}$ and ranges from the summit of the Bella Tola mountain ( 3025 m a.s.l.) to the confluence, with a drainage channel (619 m a.s.l.) draining into the Rhône River. Debris flows in the Meretschibach currently originate mainly in the Bochtür subcatchment $\left(1.42 \mathrm{~km}^{2}\right.$ area), which is covered mostly by steep debris slopes with hillslope angles on the talus deposits of up to $60 \%$. Patches of forest are present below the treeline (2200 m a.s.l.) and at the margins of the catchment, and largely contiguous forest is found along both sides of the channel below an elevation of $1600 \mathrm{~m}$. The Bochtur subcatchment is underlain by Triassic sericitized quartzite and white quartzites of the Bruneggjoch formation (Gabus et al., 2008). The surface has several terrace-like structures, which have been mapped as sackingtype features (Gabus et al., 2008) and are likely sources of landslides and rockfall.

Sediment deposits are abundant on the steep slopes of the catchment, originating from a variety of mass wasting processes. Field observations of rockfall, the presence of damaged trees, and unpublished records in the community 


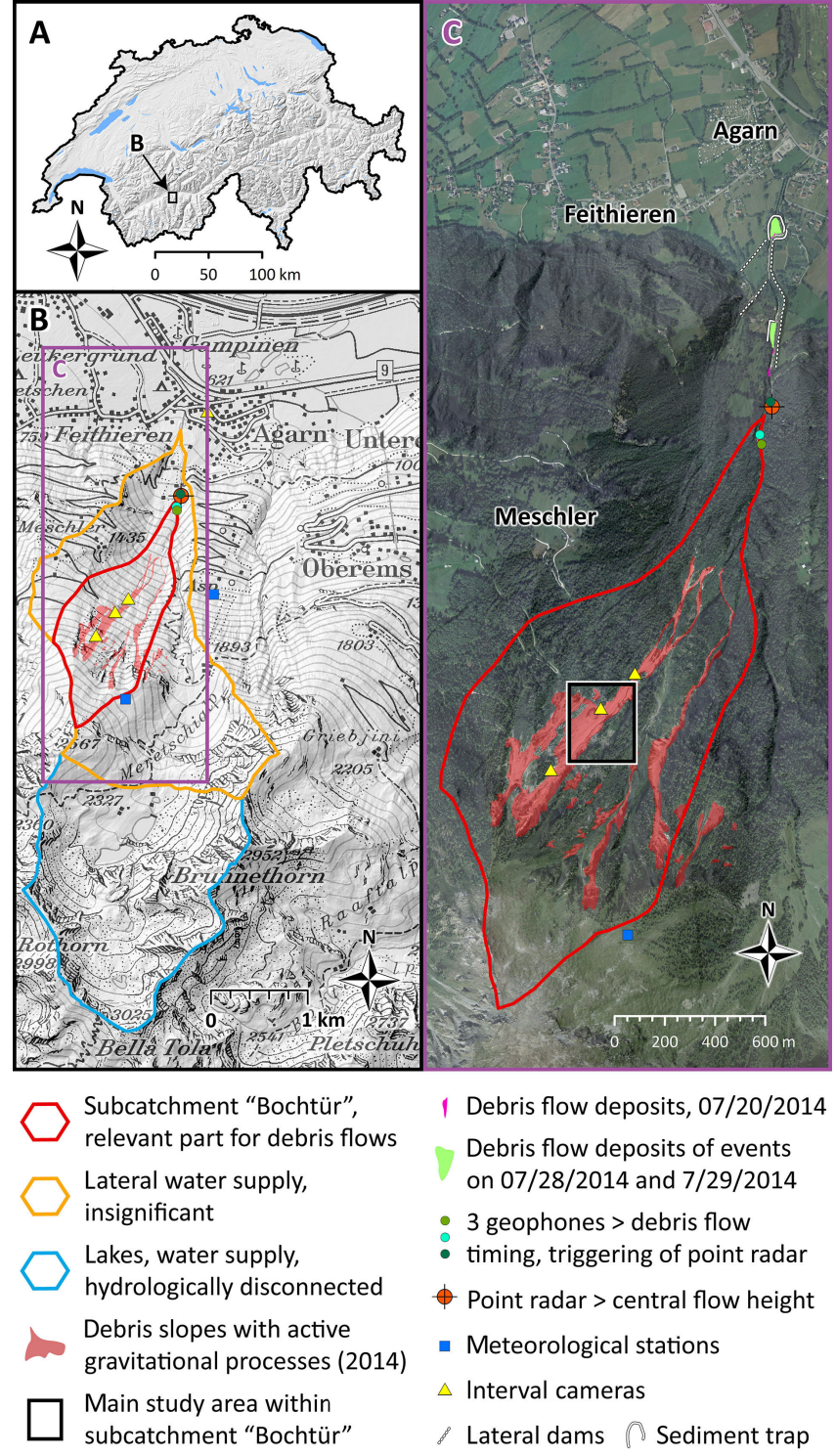

Figure 1. (a) Location of the Meretschibach catchment in southern Switzerland. (b) Subcatchments of the Meretschibach and locations of the instrumentation site and data available for the erosion model analyses (c). Initiation zone of the July 2014 events and camera positions. The main study channel reach for the model testing is located in the middle part of "Bochtür" (black-white retangle), swissimage $\odot$ 2014, swisstopo (5704 000 000) (2014). Date format: $\mathrm{MM} / \mathrm{DD} / \mathrm{YYYY}$.

forestry archives records indicate that rockfall is a dominant process for generating sediment. Observations in the source area also indicate that dry ravel of gravel and sand is also common in the summer months when the hillslopes are relatively dry. According to the event inventory, debris flows occur mainly between April and October (Szymczak et al., 2010). Small debris flows start and deposit in the upper catchment, often depositing at an area of lower slope located an elevation of approximately $2000 \mathrm{~m}$ a.s.l. Convective storms or long-duration rainfall events have been observed to mobilize these sediment deposits and initiate debris flows.

Georadar profiles on the west side of the unforested part of the Bochtür subcatchment and airborne georadar measurements indicate that the sediment deposits are up to $5 \mathrm{~m}$ thick (Lucas et al., 2017), although independent observations of the spatial distribution of sediment thickness are not available. However extrapolation of that value to other parts of the catchment must be made with caution because the profiles were made on a talus deposit, which may be interpreted as a depositional area on the hillslope, that exhibits little geomorphic evidence of debris-flow activity.

In the years 2013 and 2014 several instruments and devices were installed in the catchment. In October 2013, a meteorological station was installed above the initiation zone to measure precipitation, temperature, and snow height. Inexpensive wildlife-observation cameras that recorded images every 15 min during daylight were positioned along the most active western channel to document the changes along the active channel. A debris-flow monitoring station was installed on 23 July 2014 (Oggier et al., 2015a). It consisted of three geophones and a radar to measure the flow stage. The radar is triggered by the geophones or the meteorological station and provides detailed recordings of the debris-flow hydrograph at a resolution of $1 \mathrm{~Hz}$.

During summer 2014, three debris flows occurred. Because the monitoring station was installed after the first event (20 July 2014), no hydrograph data are available for this event. Precipitation and hydrograph data for the debris-flow events on 28 and 29 July 2014 indicate that the debris-flow event on 28 July was triggered due to convective storms with large rainfall intensity (up to $3.3 \mathrm{~mm} 10 \mathrm{~min}^{-1}$ ) while the event 29 July 2014 began after a few hours of steady rain-

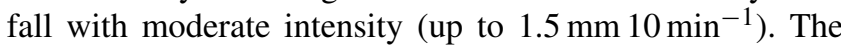
pictures from camera 4 (see Fig. 1 for the location) clearly showed that the initiation of the event on 28 July took place between 19:45 and 20:15 (UTC +2), corresponding with the hydrograph measured at the observation station.

To obtain additional information about the initial volume and the spatial distribution of erosion, the height models from 15 July and 28 October were compared. The digital elevation model of 17 July was the result of a photogrammetry flight by swisstopo. The second digital elevation model (28 October) - which is a surface model (including vegetation) - was taken with a drone (Oggier et al., 2015b). The results indicate that the volume of the events that eroded at the open debris slopes of Bochtür was between 800 and $1200 \mathrm{~m}^{3}$. Due to additional erosion downslope of the Bochtür subcatchment, the total volume of the debris-flow events was between 8000 and $10000 \mathrm{~m}^{3}$.

\subsection{Bondasca catchment, Switzerland}

The Bondasca catchment in southeastern Switzerland is a tributary to the Bergell Valley (Fig. 2). The catchment area 


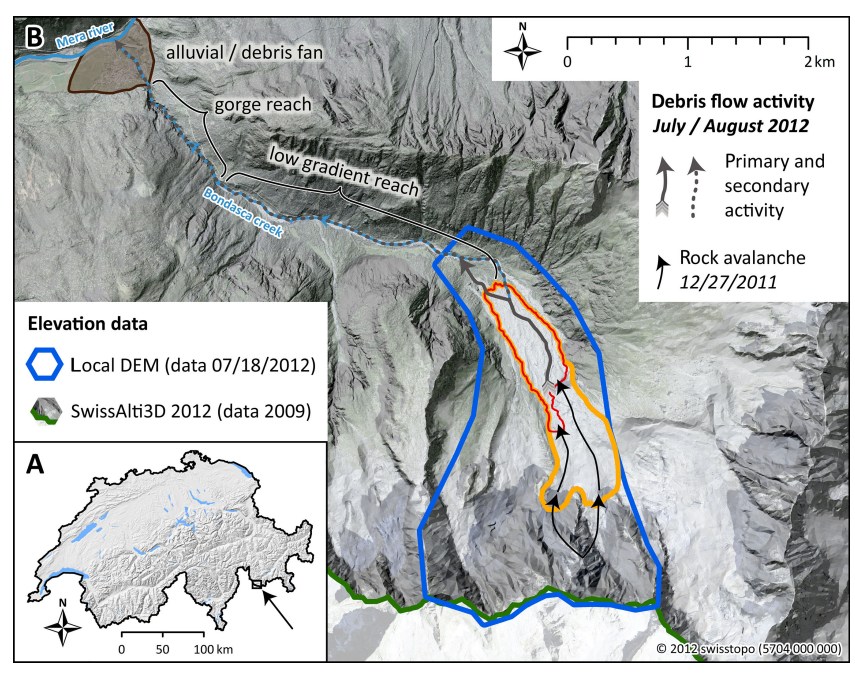

Figure 2. (a) Location of the Bondasca catchment in southeastern Switzerland close to the border to Italy. (b) Perimeter of the 27 December 2011 rock avalanche deposit, including the main deposition area (yellow polygon) and the lower-elevation deposits which were partially exposed to erosion by debris flows in 2012 (red polygon). The 2012 post-event digital elevation model (lidar, blue polygon) is from 18 July 2012 (data courtesy of the Amt für Wald, Canton Graubünden). Pre-event digital elevation model (lidar) for 2009 is from the SwissAlti3D (version 2012) data set from swisstopo@ 2012 (5704000 000). The grey solid arrow indicates the main debris-flow channel formed in 2012.

covers about $20.9 \mathrm{~km}^{2}$. The geology is dominated by the Tertiary intrusion of the Bergell granite. Originating from within the north wall of Pizzo Cengalo, a rock avalanche on 27 December 2011 deposited about $1.5 \times 10^{6} \mathrm{~m}^{3}$ of sediments in the upper catchment with a runout of up to $2 \mathrm{~km}$ from the rock wall. The deposits are up to $17 \mathrm{~m}$ thick and cover an area of about $0.760 \mathrm{~km}^{2}$, while the hydrological subcatchment is about $1.18 \mathrm{~km}^{2}$, defined by the point where the channel leaves the rock avalanche deposits at the lower end of the deposit.

The sudden sediment input from the rock avalanche was followed by several debris flows in the summer of 2012 (5 and 14 July, 25 August, 24 September), whereof the two events in July evacuated about $90000 \mathrm{~m}^{3}$ of sediments from the rock avalanche deposit (Frank et al., 2017). The debris flows originated mainly just below a planar rock face. Some of the debris-flow surges are thought to have been triggered due to water accumulation at the toe of the wall causing firehose-type debris-flow initiation (Figs. $3 b$ and 5b), e.g., as described by Godt and Coe (2007). The slope of the channel on the rock avalanche deposit varies between ca. $32^{\circ}$ $(\approx 71 \%)$ below the flat-shaped rock face and $15^{\circ}(\approx 33 \%)$ at the lower end of the rock avalanche deposit.

\section{Debris-flow entrainment modeling}

The goal of this study is to evaluate the entrainment algorithm implemented in the RAMMS debris-flow model (version 1.6.25), which has been previously described by Frank et al. (2015). In particular, the sensitivity of the predicted erosion to the input parameters will be investigated, and the data sets described above provide a new basis for evaluating the model. The previous study (Frank et al., 2015) focused on demonstrating that more realistic runout results can be achieved when including sediment entrainment and bulking into the runout model. However that study also left many unanswered questions regarding the sensitivity of the model to input parameters, especially the initial landslide volume, which was not possible to assess in the previous study. Herein we focus on describing the sensitivity of the model to the initial landslide volume, using the two well-documented events described previously.

Although the RAMMS debris model and the entrainment algorithm have been published elsewhere, they will be introduced briefly. The underlying numerical formulas of the shallow-water equation and the Voellmy friction approach used in the RAMMS debris-flow model are presented in detail in Christen et al. (2010); the entrainment model is described in Frank et al. (2015).

\subsection{Computational debris-flow model RAMMS}

The RAMMS debris-flow model is based on 2-D depthaveraged shallow-water equations for granular flows in three dimensions given by the coordinates of the topographic surface of the digital elevation model in a Cartesian coordinate system $(x, y, z)$ and at time $(t)$ (Bartelt et al., 1999, 2013; Christen et al., 2010). The mass balance equation incorporates the field variables flow height $H(x, y, t)$ and flow velocity $U(x, y, t)$ and is given by

$\dot{Q}(x, y, t)=\partial_{t} H+\partial_{x}\left(H U_{x}\right)+\partial_{y}\left(H U_{y}\right)$,

where $\dot{Q}(x, y, t)$ describes the mass production source term, and $U_{x}$ and $U_{y}$ represent the depth-averaged velocities in horizontal directions $x$ and $y$ (Christen et al., 2010). The depth-averaged momentum balance equations account for the conservation of momentum in two directions $x$ and $y$ :

$$
\begin{aligned}
S_{\mathrm{g}_{x}}-S_{\mathrm{f}_{x}} & =\partial_{t}\left(H U_{x}\right)+\partial_{x}\left(c_{x} H U_{x}^{2}+g_{z} k_{\mathrm{a} / \mathrm{p}} \frac{H^{2}}{2}\right) \\
& +\partial_{y}\left(H U_{x} U_{y}\right), \\
S_{\mathrm{g}_{y}}-S_{\mathrm{f}_{y}} & =\partial_{t}\left(H U_{y}\right)+\partial_{x}\left(H U_{x} U_{y}\right) \\
& +\partial_{y}\left(c_{y} H U_{y}^{2}+g_{z} k_{\mathrm{a} / \mathrm{p}} \frac{H^{2}}{2}\right),
\end{aligned}
$$

where the earth pressure coefficient $k_{\mathrm{a} / \mathrm{p}}$ is normally set to 1 when running the standard Voellmy-Salm friction approach, 


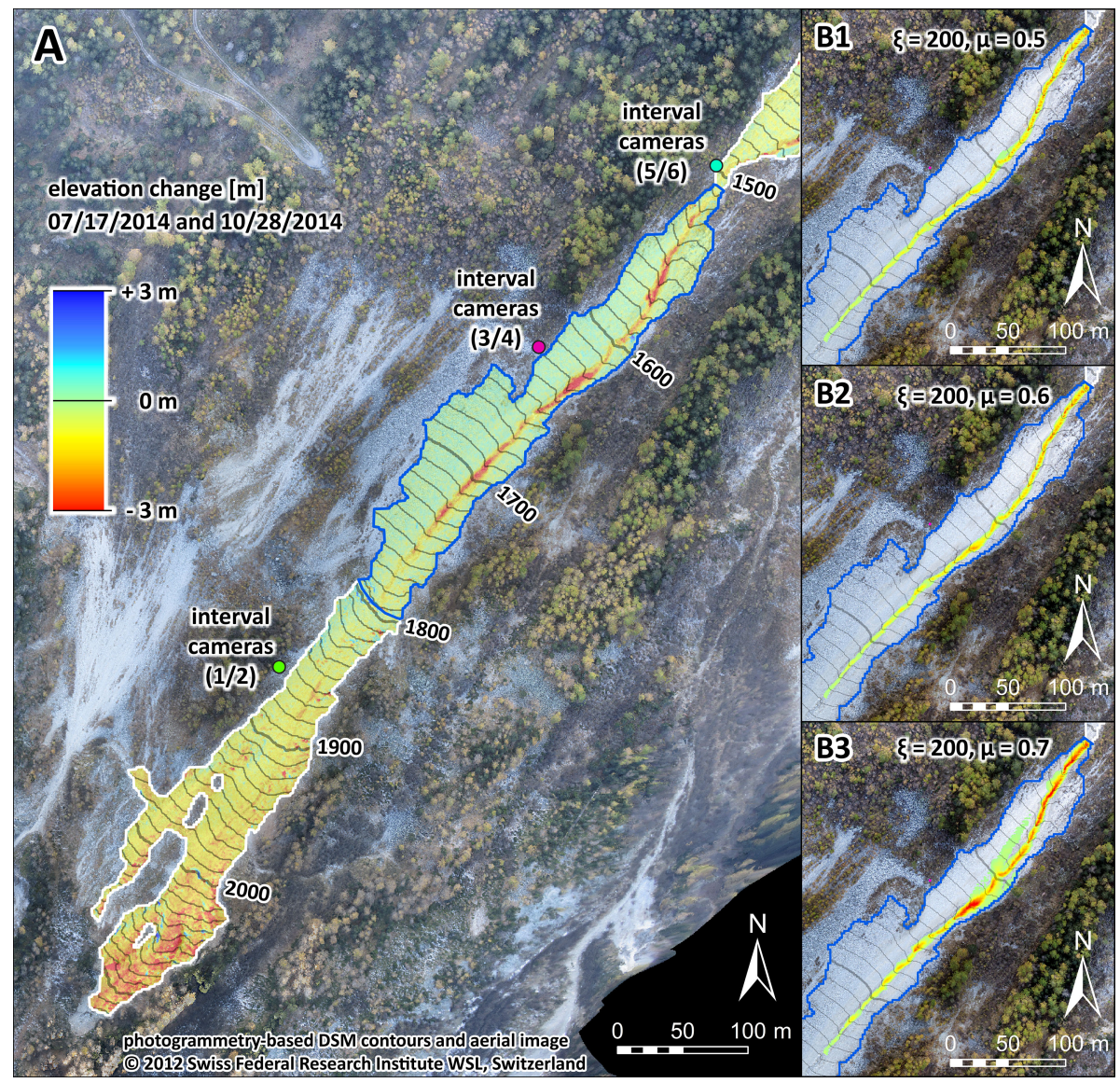

Figure 3. Calibration of modelled erosion patterns (b1 to b3) to the observed erosion depths (a) in the upper open debris slopes of the "Bochtür" catchment (Meretschibach) by varying values for the friction parameter $\mu$. The blue polygon demarks the area where a differential DTM is available.

$c_{x}$ and $c_{y}$ represent topographical coefficients determined from the digital elevation model, $S_{\mathrm{g}}$ is the effective gravitational acceleration, and $S_{\mathrm{f}}$ is the frictional deceleration in directions $x$ and $y$ (Christen et al., 2010). The frictional deceleration $S_{\mathrm{f}}$ of the flow is determined using the Voellmy friction relation (Salm et al., 1990; Salm, 1993) and specifies the dry-Coulomb term (friction coefficient $\mu$ ) scaling with the normal stress and the viscous or turbulent friction (coefficient $\xi$ ) depending on the flow velocity $U$ (Christen et al., 2010, 2012; Bartelt et al., 2013):

$$
S_{\mathrm{f}}=\mu \cdot \rho \cdot H g \cos (\phi)+\frac{\rho g U^{2}}{\xi},
$$

where $\rho$ is the mass density, $g$ is the gravitational acceleration, $\phi$ is the slope angle, and $H g \cos (\phi)$ is the normal stress on the overflowed surface. The tangent of the effective internal friction angle of the flow material can be defined for the resistance of the solid phase (the term containing $\mu$ ) which extensively controls deceleration behavior of a more slowly moving flow. The resistance of the viscous or turbulent fluid phase (the term including $\xi$ ) prevails for a more quickly moving flow (Bartelt et al., 2013).

\subsection{Debris-flow entrainment model}

The entrainment model was constructed using field data from the Illgraben catchment in Switzerland (Frank et al., 2015). The entrainment model describes the maximum erosion depth as a function of channel-bed shear stress and the vertical erosion rate of channel-bed sediment erosion. In detail, the model is based on the analysis of differential elevation models from pre- and post-event digital terrain models (DTMs) by Schürch et al. (2011). This provides the depth of net erosion in a cell as a function of the local shear stress acting on the channel bed at the base of the flow. Similarly, the rate of erosion is constrained to be at the rate reported by Berger et al. (2011), using in situ erosion sensors, also at the Illgraben channel. In the analysis of Schürch et al. (2011), flow heights were determined using values interpolated between lateral levees after each event, and the shear stress $\tau$ is approximated using the depth-slope product:

$\tau=\rho g h S$,

where $\rho$ is the bulk mass density of the flow, $h$ is flow height, and $S$ is the channel slope. An approximation of the typi- 
cal potential erosion depth at the Illgraben follows the 50thpercentile line fit to the distribution of elevation change for four debris-flow events (Fig. 3a in Schürch et al., 2011b). The entrainment algorithm implemented in the RAMMS debrisflow model is defined by the maximum potential erosion depth $e_{\mathrm{m}}$ and a specific erosion rate $\frac{\mathrm{d} z}{\mathrm{~d} t}$ (Frank et al., 2015). The relationship between the shear stress estimated (based on flow heights obserserved in the field) and the measured erosion depth (Schürch et al., 2011) is described as a linear function of shear stress using a proportionality factor $\frac{\mathrm{d} z}{\mathrm{~d} \tau}$ (Eq. 6). The maximum potential erosion depth $e_{\mathrm{m}}$ (for each grid cell) is calculated using a critical shear stress $\tau_{\mathrm{c}}(=1 \mathrm{kPa})$ and the proportionality factor $\frac{\mathrm{d} z}{\mathrm{~d} \tau}\left(=0.1 \mathrm{~m} \mathrm{kPa}^{-1}\right)$ as a function of basal shear stress $\tau$ (Frank et al., 2015):

$e_{\mathrm{m}}=\left\{\begin{array}{ll}0 & \text { for } \tau<\tau_{\mathrm{c}} \\ \frac{\mathrm{d} z}{\mathrm{~d} \tau}\left(\tau-\tau_{\mathrm{c}}\right) & \text { for } \tau \geq \tau_{\mathrm{c}}\end{array}\right.$.

The average rate of erosion recorded at the erosion sensor site during the Illgraben debris-flow event of 1 July 2008 (Berger et al., 2011) is used to define a specific erosion rate $\frac{\mathrm{d} z}{\mathrm{~d} t}$.

$\frac{\mathrm{d} z}{\mathrm{~d} t}=-0.025$ for $e_{t} \leq e_{\mathrm{m}}$

When the critical shear stress $\tau_{\mathrm{c}}$ is exceeded, sediment can be entrained from the channel. Entrainment stops when the actual erosion depth $e_{t}$ reaches the maximum potential erosion depth $e_{\mathrm{m}}$ (Eq. 6). Normally, the specific erosion rate is implemented using the default value $\frac{\mathrm{d} z}{\mathrm{~d} t}=-0.025 \mathrm{~m}^{-1}$ (Eq. 7) as presented in Frank et al. (2015). However, the model also allows accounting for larger or smaller entrainment scenarios by either doubling the rate or cutting it in half. In this study, we will use these variable erosion rates to test the sensitivity of the model.

\subsection{Entrainment model setup}

\subsubsection{Topographic resolution}

This study focuses on the evaluation of the sensitivity of the predicted (modeled) channel-bed erosion in relation to the initial volume (e.g., initial landslide size) and the comparison of the model results and the erosion pattern observed in the field. The ability to reproduce the observed erosion patterns highly depends on a realistic representation of the channel morphology where the channel is clearly visible in the DTM (Deubelbeiss et al., 2010, 2011; Scheuner et al., 2011; Hohermuth and Graf, 2014), and the channel dimensions (e.g., cross-sectional area) in the DTM have to be similar to what is observed in the field (e.g., Frank et al., 2015). In this study, the initial topographic data available for the Meretschibach catchment (described above) are on a square grid of $0.5 \mathrm{~m}$ for a channel with a width of 2 to $4 \mathrm{~m}$. At the Bondasca catchment data are available on a $2 \mathrm{~m}$ square grid for channel varying in width from about 5 to $20 \mathrm{~m}$. Although a channelwidth-to-DTM-grid-spacing ratio of more than 5 to 10 would probably produce more accurate results, such data are generally unavailable, and the increase in the time for a simulation would be impractical.

\subsubsection{Entrainment model starting condition: block release and input hydrograph}

The type of initial release mechanism, block release (e.g., landslide) or input hydrograph, can be determined based on field observations, potential model constraints, and previous modeling experience using the RAMMS debris-flow model (Bartelt et al., 2013). Recent debris-flow modeling studies (Deubelbeiss et al., 2010, 2011; Han et al., 2015) have summarized that debris flows in steep channels are mostly triggered by the sudden destabilization of material originating from lateral bank collapses or dam-type deposits located within the channel itself. Han et al. (2015) concluded that a hypothetical scenario such as the breaking of a dam - which they used to start their entrainment model simulations - provides a stable and consistent release method. Deubelbeiss et al. (2010, 2011), for a case study in the Swiss Alps, suggested that the block release method is the most appropriate method for small to moderate initial volumes ranging from $1 \mathrm{~m}^{3}$ up to $100 \mathrm{~m}^{3}$ using the RAMMS debris-flow model. The alternative release method using a discharge hydrograph seems to be more suitable for larger initial volumes (Deubelbeiss et al., 2010, 2011) $\left(>100 \mathrm{~m}^{3}\right)$, which might be plausible for the larger channel of the Bondasca catchment.

The main problem with the block release is that the initial flow depth, width, or length of the initial landslide can be unrealistically large in comparison to field observations. Users have to resort to using unrealistically large initial landslide volumes because most models do not allow for entrainment along the channel path. The total debris-flow volume, typically measured in the deposition zone, is often used as the initial landslide volume, thereby implicitly ignoring the possibility that channel-bed erosion and flow bulking occur (Frank et al., 2015). The input hydrograph starting condition in RAMMS was intended to help circumvent this problem by allowing users to specify an influx of debris as a function of time at a point lower in the watershed (e.g., just above the fan apex).

The block release volume is calculated by defining a specific block release height (with a precision of $1 \mathrm{~cm}$ in this study) based on a pre-defined release area. The model assumes an instantaneous failure of the landslide. The initial landslide surface elevation is then set to the initial elevation of the land surface using an automatic procedure in RAMMS (the subtract release from DTM option in RAMMS introduced in version 1.6.45). The main advantage of this procedure is that it prevents unrealistic lateral spreading of the initial landslide mass in comparison with a landslide "block" situated on top of the land surface. 

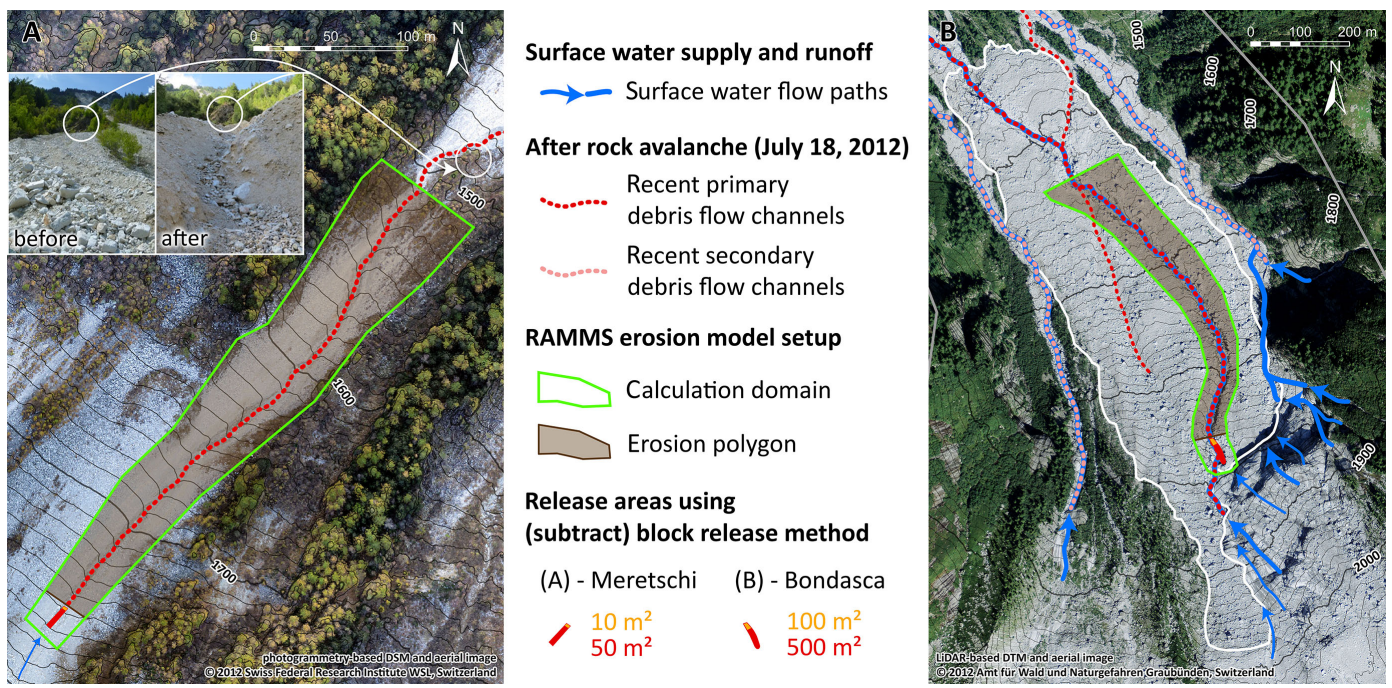

Figure 4. Erosion model configuration for the model simulations showing the initial block release areas in the Meretschibach catchment (a) and the Bondasca catchment, Switzerland (b). The hillslope is erodible within the brown-shaded polygon.

\subsubsection{Specified erosion rates}

As a basis for comparison of the sensitivity of the entrainment algorithm, we hold constant the default entrainment model coefficients (critical shear stress $\tau_{\mathrm{c}}$, potential erosion depth as a function of basal shear stress $\frac{\mathrm{d} z}{\mathrm{~d} \tau}$, erosion rate $\left.\frac{\mathrm{d} z}{\mathrm{~d} t}\right)$ described above. In the previous study (Frank et al., 2015) we demonstrated that an erosion rate of $\frac{\mathrm{d} z}{\mathrm{~d} t}=-0.025 \mathrm{~m} \mathrm{~s}^{-1}$ based on field data from the Illgraben catchment, Switzerland (Berger et al., 2011), produces plausible results for the much steeper Spreitgraben catchment. The catchments described in this paper are different in size and slope, so one might expect some variation in erosion rate. However, the entrainment algorithm in RAMMS allows for erosion rates up to $\frac{\mathrm{d} z}{\mathrm{~d} t}=-0.05 \mathrm{~m} \mathrm{~s}^{-1}$, with an option to include a shape file describing where erosion may occur, for example, to account for engineering structures such as check dams or sills, or natural features such as bedrock, where significant erosion is not expected during one debris-flow event. For comparison we also used a rate of $\frac{\mathrm{d} z}{\mathrm{~d} t}=-0.0125 \mathrm{~m} \mathrm{~s}^{-1}$ based on a lower rate from Berger et al. (2011).

\section{Erosion and entrainment: observations and modeling results}

\subsection{Erosion patterns and entrainment model calibration}

The observed erosion patterns are the basis for calibrating the RAMMS model coefficents; in particular the friction coefficients $\xi$ and $\mu$ are systematically adjusted in successive model runs until a satisfactory model result is achieved. The erosion pattern is derived by assessing the difference between the digital elevation models. In both study areas, a measured erosion pattern caused by one single debris-flow event is not available. We therefore focus on the spatial distribution of erosion and deposition, instead of attempting to exactly predict the spatial change due to the debris-flow process.

In the Meretschibach, the change in the DTM includes the erosion due to three debris-flow events which appear to have originated on an open-slope talus deposit (Fig. 3a). The location of the release area at the Meretschibach corresponds to the uppermost visible erosion scar visible in the DTM analysis and, as described above, includes the erosion due to three debris-flow events between 17 July and 28 October 2014 (Fig. 3a). Therefore, the release area was placed within the channel, where up to $2.5 \mathrm{~m}$ of erosion was observed (upper end of the blue polygon at about $1750 \mathrm{~m}$ a.s.l. in Fig. 3a). The location is just below a bedrock step intersecting the main channel at about $1800 \mathrm{~m}$ a.s.l. Further monitoring at the upper Bochtür subcatchment using interval cameras and conducting field observations at the site itself confirmed that at least some of the debris flows most likely began at this location.

We calibrated the RAMMS model using an initial block release volume of $10 \mathrm{~m}^{3}$, which corresponds to the channel depth of $1-2 m$ and a width of 2-4 $m$ at this location. To keep the initial volume within the channel and prevent unrealistic lateral outflow, the method of subtracting the initial landslide block from the elevation model was applied. Within the middle and lower channel sections (Fig. 3a, blue polygon), the observed runout and relative erosion patterns can be best reproduced using Voellmy friction parameters $\xi=200 \mathrm{~m} \mathrm{~s}^{-2}$ and $\mu=0.6$ (Fig. 3b2). The parameter $\xi$ was determined by varying it within the range proposed by the developers of the RAMMS model $(\xi=100,200,400)$ and inspecting the results (Bartelt et al., 2013). The modeled velocities of 6 
$9 \mathrm{~m} \mathrm{~s}^{-1}$ using $\xi=200$ are plausible, although independent field data are not available for comparison. The parameter combination $\xi=200 \mathrm{~m} \mathrm{~s}^{-2}$ and $\mu=0.7$ results in overbank flow along both sides of the middle channel, which was not observed in the field (Fig. 3c2). Neither deposits nor levees accumulated outside of the channel along this entire channel reach (Fig. 3a, blue polygon). In contrast, the erosion pattern using $\xi=200 \mathrm{~m} \mathrm{~s}^{-2}$ and $\mu=0.5$ resulted in an even distribution of erosion along the entire channel length, which is inconsistent with the field results which showed locations of deeper erosion depths (Fig. 3a). Within the normal range of the $\xi$ parameter (Bartelt et al., 2013) the differences in flow and erosion patterns were small in comparison to those resulting from variations in $\mu$ and are therefore not described herein. Hence, the further model runs were conducted using the best-fit parameters $\xi=200 \mathrm{~m} \mathrm{~s}^{-2}$ and $\mu=0.6$ in the sensitivity analyses described in subsequent sections.

In the Bondasca catchment, the differential elevation model includes both the rock avalanche deposit (27 December 2011) and the erosion due to one debris-flow event (5 July 2012) (Fig. 5). The upper end of channel erosion is located just below a planar outcrop of bedrock (Fig. 4b), corresponding to the likely location debris-flow initiation zone (Fig. 5c). The surface runoff channels along the west side of the wall and runoff across the wall surface (Fig. 4b) converge on the sediments at the bottom of the rock wall (see pictures from 2014 in Fig. 5). This scenario suggests a firehose-type debris-flow initiation (e.g., Godt and Coe, 2007). Hence, this location was used as the initiation area for the runout modeling.

The observed erosion along the main debris-flow channel (Fig. 5c) - resulting from the two debris-flow events in July 2012 - was used to calibrate the RAMMS model within the upper two-thirds of the study reach (Fig. 4b, brown polygon). The best fit was found with the parameter combination $\xi=400 \mathrm{~m} \mathrm{~s}^{-2}$ and $\mu=0.3$. However, the observed elevation change also includes secondary processes such as lateral bank collapse and the deposition of debris-flow snouts and levees within the channel. Channel sections where the events eroded into the deposits can also be identified by the stratigraphy in the field.

\subsection{Entrainment modeling and runout patterns}

The runout of a (landslide-type) block release of $10 \mathrm{~m}^{3}$, neglecting erosion (Fig. 6a), results in maximum flow heights smaller than $0.5 \mathrm{~m}$, and the flow stops in the channel upstream of the deposition zone. By contrast, including debrisflow erosion (Fig. 6b) leads to a more realistic flow pattern consisting of flow within the channel reaching the deposition zone without any lateral outflow. For comparison, if the total event volume $\left(\approx 1555 \mathrm{~m}^{3}\right)$ is released as a landslide and the debris flow is not allowed to erode the channel (Fig. 6c), the runout will show overbank flow along the upper channel reaches below the initiation area. The last scenario illustrates again the problems associated with starting a runout model with the entire event volume assigned to the initial volume. These results illustrate the ability of the runout model to better predict the erosion pattern and runout if the channel-bed erosion and bulking process is included in the model.

\subsection{Erosion model sensitivity testing}

The results show that the total volume of eroded sediment, at both field sites, depends strongly on the initial landslide volume. At both the Meretschibach and the Bondasca catchments, there is a strong increase in the amount of sediment entrained and consequently an increase in debris-flow volume (Fig. 7) for relatively small increases of the initial landslide volume. At the Meretschibach catchment, the entrainment model - using the default maximum erosion rate $\frac{\mathrm{d} z}{\mathrm{~d} t}=$ $-0.025 \mathrm{~m} \mathrm{~s}^{-1}$ - shows the highest sensitivity to the total erosion volume between 2 and $3 \mathrm{~m}^{3}$ of initial block release (e.g., initial landslide volume). Above $4-5 \mathrm{~m}^{3}$ of initial block volume the increase of the total erosion volume within the erosion domain remains approximately constant. The cause for the rapid increase is related to the critical shear stress in the entrainment algorithm. Small initial landslides do not generate enough shear stress to initiate erosion, whereas larger landslides can cause erosion over the entire computational domain.

If we double the erosion rate to $\frac{\mathrm{d} z}{\mathrm{~d} t}=-0.05 \mathrm{~m} \mathrm{~s}^{-1}$ based on field estimates reported by Frank et al. (2015) for the Spreitgraben catchment, a similar pattern is observed in the relationship between total erosion volume as a function of initial release volume. However the erosion volumes are 3 to 5 times larger than the ones resulting from the default erosion rate at the same initial release volume. In contrast, implementing only half the default maximum erosion rate $\left(\frac{\mathrm{d} z}{\mathrm{~d} t}=\right.$ $-0.0125 \mathrm{~m} \mathrm{~s}^{-1}$ ) for low-entrainment scenarios decreases the sensitivity to initial volume in an analogous manner.

Similar trends in total erosion volume as a function of initial block release (landslide) volume are observed at the Bondasca catchment. However, the model only starts to predict significant erosion volumes for block releases exceeding $20 \mathrm{~m}^{3}$, and the progressive increase in total erosion volume as a function of initial block release volume is somewhat less steep. For the default erosion rate $\frac{\mathrm{d} z}{\mathrm{~d} t}=-0.025 \mathrm{~m} \mathrm{~s}^{-1}$ (Frank et al., 2015), total erosion volumes increase most strongly between initial volumes of 20 to $100 \mathrm{~m}^{3}$. The topography at the Bondasca catchment is somewhat less steep and more variable, which may help explain these differences. Doubling the default erosion rate at the Bondasca catchment results in the onset of erosion for initial volumes between 20 and $30 \mathrm{~m}^{3}$. When reducing the default erosion rate to half of the default value, the erosion model depicts a somewhat less sensitive reaction of the entrainment model than using the default rate.

Further assessment of the relation of the total erosion volumes depending on the initial volumes can be made by calculating a growth rate (Hungr et al., 2005). We call it vol- 

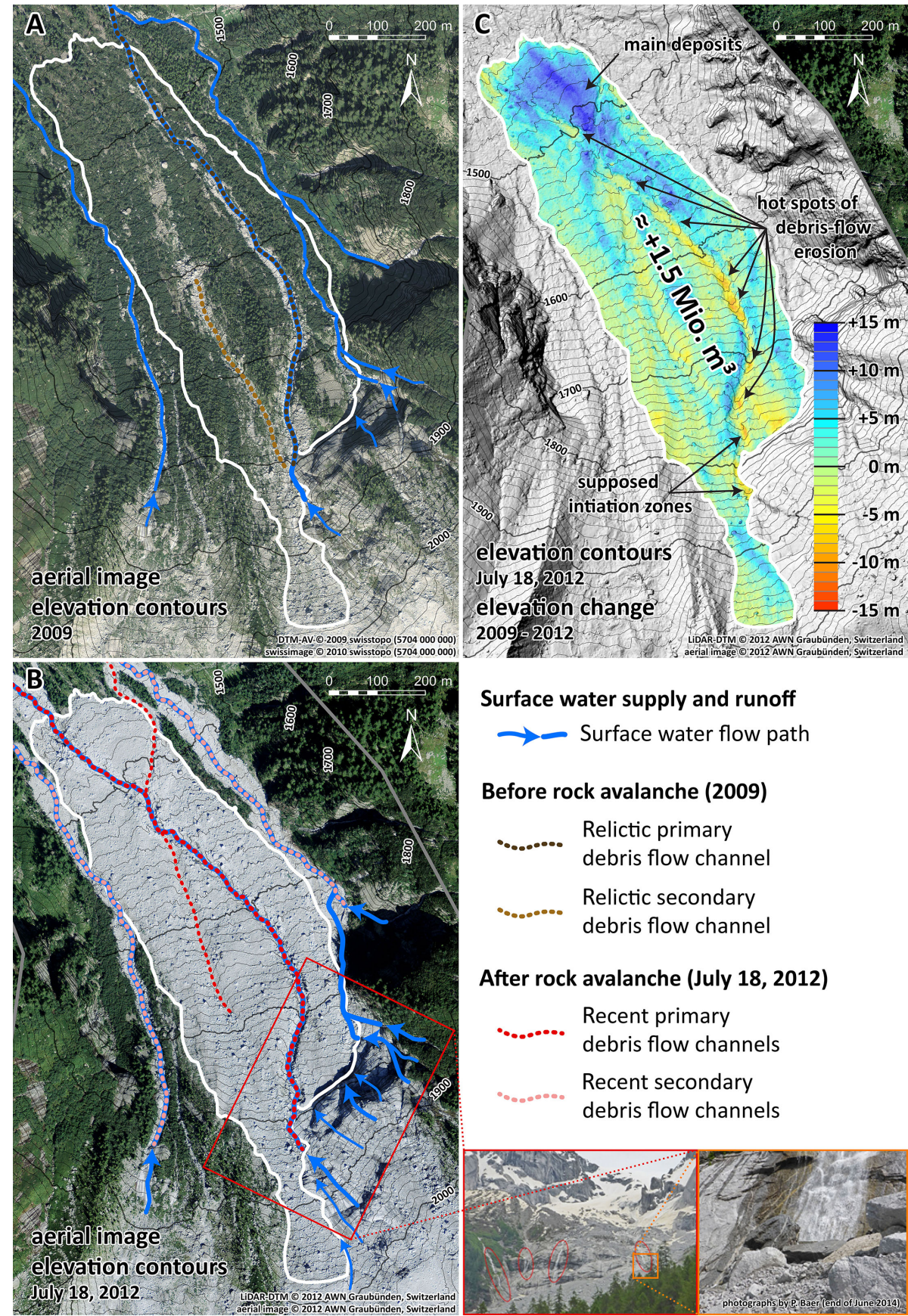

\section{Surface water supply and runoff \\ $\longrightarrow$ - Surface water flow path}

\section{Before rock avalanche (2009)}

........ Relictic primary

debris flow channel

Relictic secondary

debris flow channel

After rock avalanche (July 18, 2012)

Recent primary

debris flow channels

Recent secondary

debris flow channels

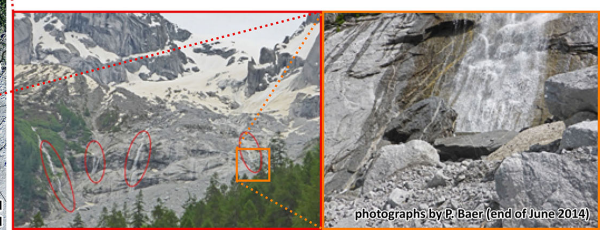

Figure 5. Overview of rock avalanche deposits, subsequently formed debris-flow channels, and the resulting overall elevation change in the

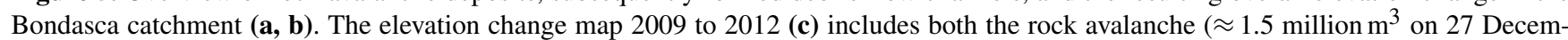
ber 2011) and the first two debris-flow events (5 and 14 July 2012).

ume growth (VG) because we address an overall ratio for a specific channel section instead of a classic "yield rate" per running meter (Hungr et al., 2005):

$\mathrm{VG}=V_{\text {final }} / V_{\text {ini }}=\left(V_{\text {ini }}+V_{\text {ero }}\right) / V_{\text {ini }}$.

The VG is the ratio of the final debris-flow volume $V_{\text {final }}$ (consisting of the initial volume $V_{\text {ini }}$ and the erosion volume
$V_{\text {ero }}$ ) to the initial volume $V_{\text {ini }}$. We analyzed the development of the VG to assess the sensitivity to various model parameters such as critical shear stress $\tau_{\mathrm{c}}$ (Fig. 8) as well as erosion rate $\frac{\mathrm{d} z}{\mathrm{~d} t}$ and initial volumes $V_{\text {ini }}$ (Fig. 9). 


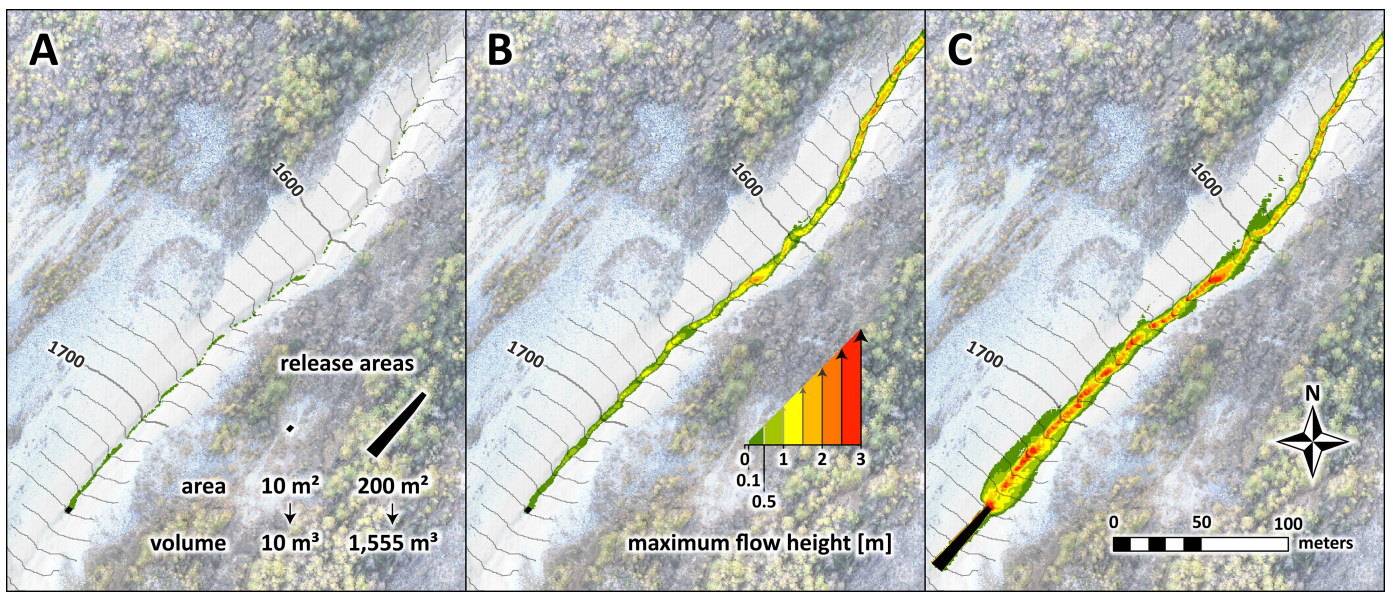

Figure 6. Comparison of runout patterns at "Bochtür" in the Meretschti catchment. The debris-flow modeling is conducted using a (subtract) block release volume of (a) $10 \mathrm{~m}^{3}$, no-entrainment modeling of (b) $10 \mathrm{~m}^{3}$, and entrainment modeling as well as a total (subtract) block release volume of (c) $1555 \mathrm{~m}^{3}$ (sum of release and eroded volume from (b) and no-entrainment modeling).

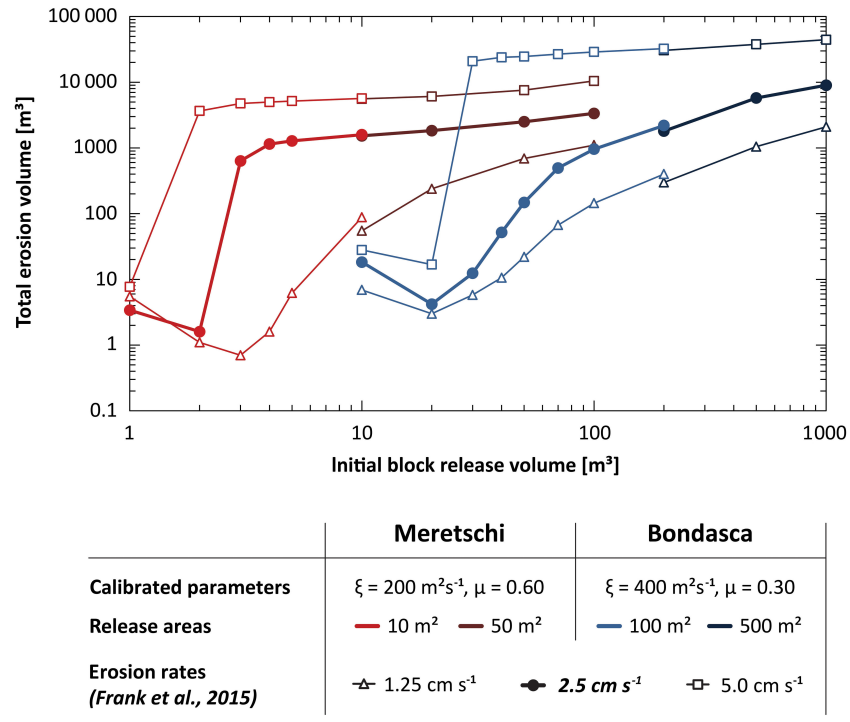

Figure 7. Sensitivity of modeled erosion volume to initial block release volume in the Meretschibach and Bondasca catchments.

\section{Discussion}

The total erosion volumes observed in the sensitivity tests (Fig. 7) indicate a strong sensitivity to block release volume (initial landslide volume) over a relatively narrow range of block release volumes. This result is based on the assumption that the entire landslide fails instantaneously and not progressively as a sequence of smaller landslides over a longer period of time. Information on the style of initial landslide failure are is available for either field site; therefore we focus the discussion on other factors related to the runout modeling. One striking difference between the two field sites is that the size of the block release necessary to cause significant ero-

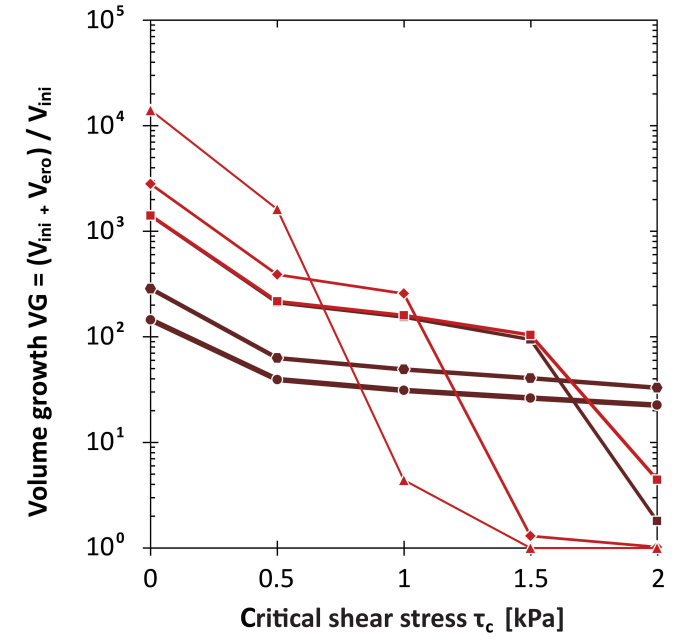

$$
\begin{array}{l|ccc|ccc|}
\text { Release areas } & \multicolumn{3}{|c}{-10 \mathrm{~m}^{2}} & \multicolumn{3}{|c}{-50 \mathrm{~m}^{2}} \\
\text { Initial release } & -- & -\downarrow- & --- & --- & --- & -\bullet- \\
\text { Volumes } & 1 \mathrm{~m}^{3} & 5 \mathrm{~m}^{3} & 10 \mathrm{~m}^{3} & 10 \mathrm{~m}^{3} & 50 \mathrm{~m}^{3} & 100 \mathrm{~m}^{3}
\end{array}
$$

Figure 8. Sensitivity of the volume growth $\mathrm{VG}=\left(V_{\text {ini }}+V_{\text {ero }}\right) / V_{\text {ini }}$ to the critical shear stress $\tau_{\mathrm{c}}$ depending on five different initial (block release) volumes $V_{\text {ini }}$ as set up based on two release areas in the Meretschibach catchment.

sion is an order of magnitude larger at the Bondasca site. The channel cross-sectional area where the flow travels and therefore where the entrainment model is active is different at the two field sites. The Meretschibach is substantially steeper (50 to $65 \%$ vs. 15 to $35 \%$ ). This results in larger shear stresses at the Meretschibach for the same initial landslide thickness, because the shear stress varies as the product of initial release thickness, flow density, and channel slope. Other factors such as differences in channel-bed roughness may also be impor- 


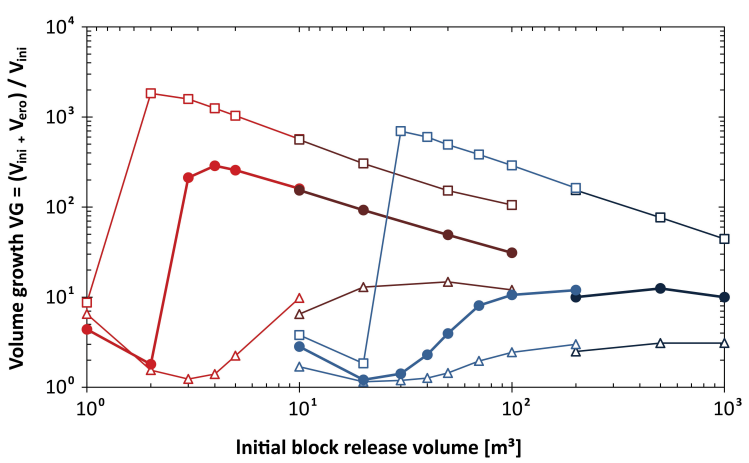

\begin{tabular}{l|c|c|} 
& Meretschi & Bondasca \\
\hline $\begin{array}{l}\text { Calibrated parameters } \\
\text { Release areas }\end{array}$ & $\xi=200 \mathrm{~m}^{2} \mathrm{~s}^{-1}, \mu=0.60$ & $\xi=400 \mathrm{~m}^{2} \mathrm{~s}^{-1}, \mu=0.30$ \\
$-10 \mathrm{~m}^{2}-50 \mathrm{~m}^{2}$ & $-100 \mathrm{~m}^{2}-500 \mathrm{~m}^{2}$ \\
$\begin{array}{l}\text { Erosion rates } \\
\text { (Frank et al., 2015) }\end{array}$ & $\checkmark 1.25 \mathrm{~cm} \mathrm{~s}^{-1} \longrightarrow 2.5 \mathrm{~cm} \mathrm{~s}^{-1} \quad-5.0 \mathrm{~cm} \mathrm{~s}^{-1}$
\end{tabular}

Figure 9. The volume growth $\mathrm{VG}=\left(V_{\text {ini }}+V_{\text {ero }}\right) / V_{\text {ini }}$ consisting of the sum of the erosion volume $V_{\text {ero }}\left(\mathrm{m}^{3}\right)$ and initial block release volume $V_{\text {ini }}\left(\mathrm{m}^{3}\right)$ per initial block release volume $V_{\text {ini }}\left(\mathrm{m}^{3}\right)$ and adressing three different erosion rates for the Meretschibach and Bondasca catchments.

tant; however the Voellmy friction relation within RAMMS does not explicitly consider channel-bed roughness.

In the RAMMS debris-flow model, the development of the flow properties is controlled by the Voellmy friction parameters $\xi$ and $\mu$ (described in Sect. 3.1), where $\xi$ is the dominant control over the flow velocities when the flow is moving rapidly and $\mu$ controls the runout distance (Bartelt et al., 2013). The $\xi$ parameter was found in this study to have a relatively small influence over the flow behavior in comparison with the Coulomb friction term $\mu$. However, a calibration of the parameter $\xi$ using an approximate discharge (block release volume or hydrograph implementation) and as observed at a particular channel section can help determine the most plausible $\xi$ valaue within the ranges proposed by the developers of the RAMMS model $(\xi=100,200,400)$ (Bartelt et al., 2013). The RAMMS manual (Bartelt et al., 2013) suggests using the tangent of the fan slope as a first estimate to determine $\mu$. As described in the calibration procedure (Sect. 4.1), this corresponds to relative erosion patterns determined by differential DTM analysis. Hence, we conclude that the tangent of the channel slope can be used as a first approach to define parameter $\mu$ also for the entrainment model when applied to channel sections which exhibit a roughly constant channel slope. This was also found to be useful by Frank et al. (2015) in the first application of the model.

For some field studies, applying this two-stage calibration method (inactive vs. active entrainment model) will benefit model users who previously conducted RAMMS runout modeling studies without entrainment. They can enhance their exisiting calibration procedure of parameter $\xi$ and $\mu$ by mainly refining on parameter $\mu$ to reflect a documented, relative erosion pattern when activating the entrainment model. In that sense, this method might be primarily limited by the potential lack of field data (flow heights, discharge, erosion patterns) which were available in this study. However, more case studies are needed before we are able to draw any general conclusions regarding potential benefits and limits of this enhanced methodology for the RAMMS entrainment model application.

In general, morphological effects influence the erosional behavior of the field-data-based entrainment model. The Bondasca channel is more variable in width and planform direction than the comparably uniform and straight Meretschibach channel. This difference will cause larger spatial variability in shear stress at Bondasca channel and therefore the channel will have a more variable onset of debrisflow erosion along the length of the channel. In the Bondasca catchment, the channel where erosion takes place is significantly wider (4-10 m) than in the Meretschibach (1-3 m). On the one hand, the flow can laterally spread more often in the Bondasca than in the Meretschibach, thereby locally reducing flow height, shear stresses, and maximum potential erosion depth. On the other hand, once the critical shear stress is exceeded, the potential erosion depth tends to increase more rapidly in a narrow channel such as in the Meretschibach channel.

Other studies have adressed the spatiotemporal variation of bed entrainment interplaying with debris-flow rheology (Cuomo et al., 2014, 2016). In RAMMS, we do not adjust the Voellmy friction coefficients as a function of flow properties because data to support the implementation of bed entrainment-flow properties interplay is not available for the catchments addressed herein (Meretschibach and Bondasca).

Another difference between the Meretschibach and the Bondasca channels is that the Bondasca channel bed has a rougher surface with more scours holes, and larger blocks within the channel which are similar in size to the nominal width of the channel. The model does not consider local variations in erodibility due to the presence of large blocks, so local scour patterns in the field around the large blocks are not present in the model results. Prancevic and Lamb (2015a) suggested that in rough mountain channels the large particles can be interlocked and hence more stable. In contrast, local concentration of the flow between such large blocks may cause locally very large shear stresses and corresponding large erosion rates. However, we do not have enough information on the mobility of the large blocks, so this question cannot be addressed in more detail herein.

The current version of the RAMMS debris-flow model with entrainment (version 1.6.45) does not adjust the elevation of the bed when erosion occurs. The erosion can be subtracted from the initial DTM as a post-processing step within the user interface, e.g., for modeling subsequent surges. This issue was discussed at length by Frank et al. (2015), and it can potentially complicate the interpretation of erosion pat- 
terns resulting from multiple debris flows. Insufficient field data are available to help constrain the events described herein.

For the sensitivity assessment of VG to the critical shear stress $\tau_{\mathrm{c}}$, we selected the Meretschibach catchment because it has a simple single-channel morphology and therefore serves as a clear case for illustration (Fig. 8). Because the erosive channel reach addressed in our study shows steep slopes reaching 50 to $65 \%$, the resulting shear stresses are very high - even for very low flow heights and small initial volumes (1$\left.10 \mathrm{~m}^{3}\right)$. This leads to a high model susceptibility to erosion (volumes) and volume growth when $\tau_{\mathrm{c}}=0 \mathrm{kPa}$ which results in scenarios of a few cubic meters of initial volumes eroding some 1000 to more than $10000 \mathrm{~m}^{3}$ (Fig. 8). However the initial landslides observed at the Meretschibach were larger in volume, suggesting that a critical shear stress is appropriate. Small debris flows do not necessarily erode the channel bed, which has been observed in the field, e.g., at the Illgraben (Berger et al., 2010a, 2011; Schürch et al., 2011). The presence of a critical shear stress in steep channels is also supported by investigations of entrainment in torrential sediment transport (Lamb et al., 2008), although we are not aware of any systematic investigations of the critical shear stress for entrainment by landslides or debris flows.

The results show that when exceeding $\tau_{\mathrm{c}}=0.5 \mathrm{kPa}$, the volume growth remains steady within a value range of 20 to 60 for middle to larger initial volumes $\left(\geq 10-50 \mathrm{~m}^{3}\right)$. Smaller initial volumes $\left(\leq 5-10 \mathrm{~m}^{3}\right)$ show much more variation; i.e., they are more sensitive to the critical shear stress. We conclude that a value of $\tau_{\mathrm{c}}=1 \mathrm{kPa}$ produces plausible results and we use that value for the other sensitivity tests in this study. However it may be possible to constrain this value at other field sites if small non-erosive debris flows can be identified and used to better constrain $\tau_{\mathrm{c}}$. The critical shear stress of $\tau_{\mathrm{c}}=1 \mathrm{kPa}$ used herein will be applied for further sensitivity analysis.

The sensitivity to initial landslide volume is apparent at the Meretschibach. Using the default erosion rate and an initial volume of $3 \mathrm{~m}^{3}$, a volume growth of $\approx 200$ is reached. A maximum of $\mathrm{VG}=300$ is observed for an initial release volume of $4 \mathrm{~m}^{3}$. It then drops to a $V G \approx 30$ for an initial volume of $100 \mathrm{~m}^{3}$. The model simulations using the doubled default erosion rate show a volume growth peak $\mathrm{VG}_{\mathrm{p}} \approx 1800$ for an initial release volume of $2 \mathrm{~m}^{3}$; half the default erosion rate shifts this peak to $50 \mathrm{~m}^{3}$ for the initial volume but the corresponding volume growth peak drops significantly down to $\mathrm{VG}_{\mathrm{p}} \approx 14$.

The behavior of the volume growth for the default erosion rate at the Bondasca catchment is relatively smooth when compared to that at the Meretschibach. But when comparing erosion patterns as modeled using 10 vs. $20 \mathrm{~m}^{3}$ as the initial volume in the Bondasca case, for example, we observed that the model run using $20 \mathrm{~m}^{3}$ is large enough that part of the flow enters a secondary channel. The volume of the flow, then divided among two channels, causes a reduc- tion in flow depth and a consequent decrease in shear stress, resulting in smaller erosion depths and therefore smaller erosion volumes - leading to lower volume growth approaching a value of $1(\mathrm{VG} \approx 1.2)$ for $V_{\text {ini }}=20 \mathrm{~m}^{3}$ compared to $\mathrm{VG} \approx 3$ for $V_{\text {ini }}=10 \mathrm{~m}^{3}$. When using an initial volume of $10 \mathrm{~m}^{3}$ then the flow remains entirely in the main channel. This may provide an explanation for the dip in the Bondasca volume growth between $V_{\mathrm{ini}}=10 \mathrm{~m}^{3}$ and $V_{\mathrm{ini}}=20 \mathrm{~m}^{3}$.

A volume growth peak can be identified between 200 and $500 \mathrm{~m}^{3}$ but the value is lower in comparison $(\approx 10-12.5)$ for the default erosion rate. The doubled rate leads to a volume growth peak $\mathrm{VG}_{\mathrm{p}}$ of $\approx 700$ at a release volume of $30 \mathrm{~m}^{3}$. That is large compared to examples in the literature (VG from 10 to 50 reported by Berti et al. (1999) and Vandine and Bovis (2002)).

Nevertheless, a several hundred fold increase of the debrisflow volume due to bulking is plausible for extreme entrainment cases. Larger erosion rates might be expected for pyroclastic deposits (not present in the catchments described herein) or due to the presence of very recent rock avalanche deposits which may contain firn-ice-debris mixtures (e.g., Spreitgraben, Tobler et al., 2014; Frank et al., 2015). Such highly erosive events represent an inherent feedback in the entrainment process whereby a rapid (e.g., double) erosion rate results in a more rapid increase in flow depth leading to larger shear stresses and then to even larger potential erosion depths. This can potentially explain the very rapid growth of debris flows, which is has been observed in some natural field cases (e.g., Spreitgraben; Tobler et al., 2014; Frank et al., 2015) and also in laboratory experiments involving realistic debris-flow sediments (e.g., video documentation of experiments at the USGS Debris-flow flume 1992-2006; Logan and Iverson, 2007).

In addition, large erodibilities may be expected at the Bondasca catchment because the rock avalanche event occurred during winter and may have contained significant amount of snow. However, due to the very long $(\approx 4 \mathrm{~km})$ and flat $(\approx 15 \%)$ channel section in the middle segment of the Bondasca catchment, the estimated deposition volumes $\left(\approx 40000 \mathrm{~m}^{3}\right)$ above the inlet of the Bondasca river in the central valley are highly influenced by further erosional and depositional processes along the channel.

\section{Conclusion}

Debris-flow runout predictions can be improved when considering the increase in flow volume along the flow path. Using a recently introduced empirical entrainment algorithm within the RAMMS 2-D runout model (Frank et al., 2015) we illustrate that runout patterns at the Meretschibach and Bondasca catchments, in Switzerland, can be accurately modeled. When calibrated with field data, the model produces more realistic runout patterns compared to simulations which do not consider entrainment and bulking. In particular, we 
could show that even in very steep $(\approx 60-65 \%)$ and narrow (4-6 m) torrent channels, lateral overflow - not observed in the field case - is prevented when applying the entrainment model. However the model results can be quite sensitive to the volume of the initial block release in the model which corresponds to the initial landslide volume. The predicted erosion volumes are sensitive to the initial debris-flow volume, with volume growth values approaching 2000 predicted by the model, depending on the scenario considered. However, the results are also sensitive to slope angle and channel morphology. The two field sites differ substantially: the Meretschibach catchment is very steep with a straight and narrow channel, whereas the Bondasca channel is less steep and morphologically more complex, yet the calibration procedure is the same as for the standard RAMMS model which does not include the entrainment process. The overall method presented herein is useful for case studies where sufficient data are available to constrain the model results. However, more case studies have to be conducted to develop a more comprehensive recommendation for modeling the runout of erosive debris flows in natural terrain.

Data availability. The data sets in this publication will be made available at the ENVIDAT online data portal, which is currently in development at the Swiss Federal Institute for Forest, Snow and Landscape Research WSL http://www.envidat.ch.

Competing interests. The authors declare that they have no conflict of interest.

Acknowledgements. This project was partially supported by the CCES-TRAMM project. We are grateful to Christian Huggel for helpful discussions and comments. We thank Martin Keiser of Amt für Wald und Naturgefahren of Canton Graubünden for providing elevation data for the Bondasca catchment and Ruedi Bösch, WSL, for the elevation data at the Meretschibach catchment. The debris-flow observations at the Meretschibach were partially financed by SNF Project 200021_144362/1 as well as related contributions by the Canton of Valais and the community of Agarn. We are grateful to Sarah Springmann (ETH) and Andrew Kos (ETH and Terrasense LTD) for insightful discussions on the stability of the Meretschibach catchment.

Edited by: M. Keiler

Reviewed by: Z. Han and one anonymous referee

\section{References}

Bartelt, P., Salm, B., and Gruber, U.: Calculating dense-snow avalanche runout using a Voellmy-fluid model with active/passive longitudinal straining, J. Glaciol., 45, 242-254, 1999.
Bartelt, P., Buehler, Y., Christen, M., Deubelbeiss, Y., Graf, C., and McArdell, B. W.: RAMMS - rapid mass movement simulation, A modeling system for debris flows in research and practice, user manual v1.5, debris flow, manuscript update: 31 January 2013, WSL Institute for Snow and Avalanche Research SLF, available at: http://ramms.slf.ch/ramms/downloads/RAMMS_DBF_ Manual.pdf (last access: 27 February 2015), 2013.

Beguería, S., Van Asch, Th. W. J., Malet, J.-P., and Gröndahl, S.: A GIS-based numerical model for simulating the kinematics of mud and debris flows over complex terrain, Nat. Hazards Earth Syst. Sci., 9, 1897-1909, https://doi.org/10.5194/nhess-9-18972009, 2009.

Benda, L.: The influence of debris flows on channels and valley floors in the Oregon Coast Range, USA, Earth Surf. Proc. Land., 15, 457-466, 1990.

Berger, C., McArdell, B. W., Fritschi, B., and Schlunegger, F.: A novel method for measuring the timing of bed erosion during debris flows and floods, Water Resour. Res., 46, W02502, https://doi.org/10.1029/2009WR007993, 2010a.

Berger, C., McArdell, B. W., and Schlunegger, F.: Sediment transfer patterns at the Illgraben catchment, Switzerland: Implications for the time scales of debris flow activities, Geomorphology, 125, 421-432, 2010b.

Berger, C., McArdell, B. W., and Schlunegger, F.: Direct measurement of channel erosion by debris flows, Illgraben, Switzerland, J. Geophys. Res., 116, F01002, https://doi.org/10.1029/2010JF001722, 2011.

Berti, M., Genevois, R., Simoni, A., and Tecca, P. R.: Field observations of a debris flow event in the Dolomites, Geomorphology, 29, 265-274, 1999.

Breien, H., De Blasio, F. V., Elverhøi, A., and Høeg, K.: Erosion and morphology of a debris flow caused by a glacial lake outburst flood, western Norway, Landslides, 5, 271-280, 2008.

Cannon, S. H. and Reneau S. L.: Conditions for generation of firerelated debris flows, Capulin Canyon, New Mexico, Earth Surf. Proc. Land., 25, 1103-1121, 2000.

Cascini, L., Cuomo, S., Pastor, M., Sorbino, G., and Piciullo, L.: SPH run-out modelling of channelised landslides of the flow type, Geomorphology, 214, 502-513, https://doi.org/10.1016/j.geomorph.2014.02.031, 2014.

Christen, M., Kowalski, J., and Bartelt, P.: RAMMS: Numerical simulation of dense snow avalanches in three-dimensional terrain, Cold Reg. Sci. Technol., 63, 1-14, 2010.

Christen, M., Bühler, Y., Bartelt, P., Leine, R., Glover, J., Schweizer, A., Graf, C., McArdell, B. W., Gerber, W., Deubelbeiss, Y., Feistl, T., and Volkwein, A.: Integral hazard management using a unified software environment: numerical simulation tool "RAMMS" for gravitational natural hazards, edited by: Koboltschnig, G., Hübl, J., and Braun, J., 12th Congress INTERPRAEVENT, 23-26 April 2012 Grenoble, France, Proceedings, Vol. 1, Klagenfurt, International Research Society INTERPRAEVENT, 77-86, 2012.

Crosta, G. B., Imposimato, S., and Roddeman, D. G.: Numerical modelling of large landslides stability and runout, Nat. Hazards Earth Syst. Sci., 3, 523-538, https://doi.org/10.5194/nhess3-523-2003, 2003.

Cuomo, S., Pastor, M., Cascini, L., and Castorino, G. C.: Interplay of rheology and entrainment in debris avalanches: 
a numerical study, Can. Geotech. J., 51, 1318-1330, https://doi.org/10.1139/cgj-2013-0387, 2014.

Cuomo, S., Pastor, M., Capobianco, V., and Cascini, L.: Modelling the space-time evolution of bed entrainment for flow-like landslides, Eng. Geol., 212, 10-20, https://doi.org/10.1016/j.enggeo.2016.07.011, 2016.

D’Ambrosio, D., Di Gregorio, S., and Iovine, G.: Simulating debris flows through a hexagonal cellular automata model: SCIDDICA $\mathrm{S}_{3-\mathrm{hex}}$, Nat. Hazards Earth Syst. Sci., 3, 545-559, https://doi.org/10.5194/nhess-3-545-2003, 2003.

Deubelbeiss, Y. and McArdell, B. W.: Dynamic modelling of debris-flow erosion and deposition with application to the USGS debris flow flume experiments, Geophys. Res. Abstr., 14, EGU2012-7906, 22-27 April 2012.

Deubelbeiss, Y., Graf, C., McArdell, B., and Bartelt, P.: Numerical modeling of debris flows - Case study at Dorfbach, Randa, (VS), Abstract Volume, 8th Swiss Geoscience Meeting, Fribourg, 1920 November 2010.

Deubelbeiss, Y., Graf, C., McArdell, B. W., and Bartelt, P.: Numerical modeling of debris flows - Case study at Dorfbach, Randa (Valais, Switzerland), Geophys. Res. Abstr., Vol. 13, EGU20115681, EGU General Assembly 2011, Vienna, 3-8 April 2011.

Dietrich, W. E. and Dunne, T.: Sediment budget for a small catchment in mountainous terrain, Z. Geomorphology, 29, 191-206, 1978.

Fannin, R. J. and Wise, M. P.: An empirical_statistical model for debris flow travel distance, Can. Geotech. J., 38, 982-994, 2001.

Frank, F., McArdell, B. W., Huggel, C., and Vieli, A.: The importance of entrainment and bulking on debris flow runout modeling: examples from the Swiss Alps, Nat. Hazards Earth Syst. Sci., 15, 2569-2583, https://doi.org/10.5194/nhess-152569-2015, 2015.

Frank, F., Huggel, C., McArdell, B. W., and Vieli, A.: Sediment input and debris flow system activity cycles - an analysis of the development in different catchments in Switzerland, Earth Surf. Proc. Land., in preparation, 2017.

Gabus, J. H., Weidmann, M., Bugnon, P.-C., Burri, M., Sartori, M., and Marthaler, M.: Geological map of Sierre, LK 1278, sheet 111 , scale $1: 25000$, in Geological Atlas of Switzerland, Swiss Geol. Surv., Bern, Switzerland, 2008.

Gallino, G. L. and Pierson, T. C.: The 1980 Polallie Creek debris flow and subsequent dam-break flood, East Fork Hood River Basin, Oregon, US Geol. Surv. Open File Rep., 84-578, 37 pp., 1984.

Gamma, P.: "dfwalk" Ein Murgang-Simulationsmodell zur Gefahrenzonierung, Institute of Geography, University of Berne, Geographica Bernensia G66, 2000 (in German).

Gartner, J. E., Cannon, S. H., Santi, P. M., and Dewolfe, V. G.: Empirical models to predict the volumes of debris flows generated by recently burned basins in the western US, Geomorphology, 96, 339-354, 2008.

Godt, J. W. and Coe, J. A.: Alpine debris flows triggered by a 28 July 1999 thunderstorm in the central Front Range, Colorado, Geomorphology, 84, 80-97, https://doi.org/10.1016/j.geomorph.2006.07.009, 2007.

Guthrie, R. H., Hockin, A., Colquhoun, L., Nagy, T., Evans, S. G., and Ayles, C.: An examination of controls on debris flow mobility: Evidence from coastal British Columbia, Geomorphology, 114, 601-613, 2010.
Han, Z., Chen, G., Li, Y., Tang, C., Xu, L., He, Y., Huang, X., and Wang, W.: Numerical simulation of debris-flow behavior incorporating a dynamic method for estimating the entrainment, Eng. Geol., 190, 52-64, https://doi.org/10.1016/j.enggeo.2015.02.009 (last access: 10 February 2016), 2015.

Hohermuth, B. and Graf, C.: Einsatz numerischer Murgangsimulationen am Beispiel des integralen Schutzkonzepts Plattenbach Vitznau, Wasser Energ. Luft, 106, 285-290, available at: http://www.wsl.ch/wsl/info/mitarbeitende/grafc/pdf/14138.pdf (last access: 10 February 2016), 2014.

Hungr, O. and McDougall, S.: Two numerical models for landslide dynamic analysis, Comput. Geosci., 5, 978-992, 2009.

Hungr, O., Morgan, G. C., and Kellerhals, R.: Quantitative analysis of debris torrent hazards for design of remedial measures, Can. Geotech. J., 21, 663-677, 1984.

Hungr, O., McDougall, S., and Bovis, M.: Entrainment of material by debris flows, in: Debris-Flow Hazards and Related Phenomena, edited by: Jakob, M. and Hungr, O., 135-158, Springer, New York, 2005.

Hussin, H. Y., Quan Luna, B., van Westen, C. J., Christen, M., Malet, J.-P., and van Asch, Th. W. J.: Parameterization of a numerical 2-D debris flow model with entrainment: a case study of the Faucon catchment, Southern French Alps, Nat. Hazards Earth Syst. Sci., 12, 3075-3090, https://doi.org/10.5194/nhess12-3075-2012, 2012.

Iverson, R. M.: The Physics of Debris Flows, in: Reviews of Geophysics, 35, 245-296, 97RG00426, 1997.

Iverson, R. M., Reid, M. E., Logan, M., LaHusen, R. G., Godt, J. W., and Griswold, J. G.: Positive feedback and momentum growth during debris-flow entrainment of wet bed sediment, Nat. Geosci., 4, 116-121, https://doi.org/10.1038/NGEO1040, 2011.

Lamb, M. P., Dietrich, W. E., and Venditti, J. G.: Is the critical Shields stress for incipient sediment motion dependent on channel-bed slope?, J. Geophys. Res., 113, F02008, https://doi.org/10.1029/2007JF000831, 2008.

Logan, M. and Iverson, R. M.: Video documentation of experiments at the USGS Debris-flow flume 1992-2006, US Geological Survey Open-File Report 2007-1315, 2007.

Lucas, D. R., Fankhauser, K., and Springman S. M.: Application of geotechnical and geophysical field measurements in an active alpine environment, Eng. Geol., 219, 32-51, https://doi.org/10.1016/j.enggeo.2016.11.018, 2017.

May, C. L.: Debris flows through different forest age classes in the Central Oregon Coast Range, J. Am. Water Resour. Assoc., 38, 1097-1113, 2002.

McCoy, S. W., Kean, J. W., Coe, J. A., Tucker, G. E., Staley, D. M., and Wasklewicz, T. A.: Sediment entrainment by debris flows: In situ measurements from the headwaters of a steep catchment, J. Geophys. Res., 117, F03016, https://doi.org/10.1029/2011JF002278, 2012.

Medina, V., Hürlimann, M., and Bateman, A.: Application of FLATModel a 2-D finite volume code, to debris flows in the northeastern part of the Iberian Peninsula, Landslides, 5, 127-142, 2008.

Meyer, G. A. and Wells, S. G.: Fire-related sedimentation events on alluvial fans, Yellowstone National Park, USA, J. Sediment. Res., 67, 776-791, 1997.

Oggier, N. and McArdell, B. W.: Ereignisanalyse - Murgangereignisse Meretschibach 20./28./29. Juli 2014, WSL Birmensdorf, 21. Januar 2015, unpublished report, 2015a (in German). 
Oggier, N. and Bösch, R.: Zwischenbericht, Drohnenflug Meretschibach 28. Oktober 2014, WSL Birmensdorf, 26. Februar 2015, unpublished report, 2015b (in German).

Pastor, M., Haddad, B., Sorbino, G., Cuomo, S., and Drempetic, V.: A depth-integrated, coupled SPH model for flow-like landslides and related phenomena, Int. J. Numer. Anal. Meth. Geomech., 33, 143-172, https://doi.org/10.1002/nag.705, 2009.

Pierson, T. C., Janda, R. J., Thouret, J-C., and Borrero, C. A.: Perturbation and melting of snow and ice by the 13 November 1985 eruption of Nevado del Ruiz, Colombia, and consequent mobilization, flow and deposition of lahars, J. Volcanol. Geotherm. Res., 41, 17-66, 1990.

Prancevic, J. P. and Lamb, M. P.: Particle friction angles in steep mountain channels, J. Geophys. Res. Earth Surf., 120, 242-259, https://doi.org/10.1002/2014JF003286, 2015a.

Prancevic, J. P. and Lamb, M. P.: Unraveling bed slope from relative roughness in initial sediment motion, J. Geophys. Res. Earth Surf., 120, 474-489, https://doi.org/10.1002/2014JF003323, 2015b.

Procter, J., Cronin, S. J., Fuller, I. C., Lube, G., and Manville, V.: Quantifying the geomorphic impacts of a lake-breakout lahar, Mount Ruapehu, New Zealand, Geology, 38, 67-70, 2010.

Revellino, P., Hungr, O., Guadagno, F. M., and Evans, S. G.: Velocity and runout simulation of destructive debris flows and debris avalanches in pyroclastic deposits, Campania region, Italy, Environ. Geol., 45, 295-311, 2004.

Salm, B., Burkard, A., and Gubler, H.: Berechnung von Fliesslawinen: eine Anleitung für Praktiker mit Beispielen, Eidg. Institut für Schnee- und Lawinenforschung SLF, 7 Davos. Mitteilung 47, 1990.

Salm, B.: Flow, flow transition and runout distances of flowing avalanches, Ann. Glaciol., 18, 221-226, 1993.

Scheuner, T., Keusen, H., McArdell, B. W., and Huggel, C.: Murgangmodellierung mit dynamisch-physikalischem und GISbasiertem Fliessmodell, Fallbeispiel Rotlauigraben, Guttannen, August 2005, Wasser Energie Luft, 101, 15-21, 2009 (in German).
Scheuner, T., Schwab, S., and McArdell, B. W.: Application of a two-dimensional numerical model in risk and hazard assessment in Switzerland, in 5th DFHM, Padua, Italy, 2011.

Schürch, P., Densmore, A. L., Rosser, N. J., and McArdell, B. W.: Dynamic controls on erosion and deposition on debris-flow fans, Geology, 39, 827-830, 2011.

Scott, K. M., Vallance, J. W., Kerle, N., Macias, J. L. Strauch, W., and Devoli, G.: Catastrophic precipitationtriggered lahar at Casita volcano, Nicaragua: Occurrence, bulking and transformation, Earth Surf. Proc. Land., 30, 59-79, https://doi.org/10.1002/esp.1127, 2005.

Suwa, H. and Okuda, S.: Dissection of valleys by debris flow, Z. Geomorphology, 35, 164-182, 1980.

Szymczak, S., Bollschweiler, M., Stoffel, M., and Dikau, R.: Debris-flow activity and snow avalanches in a steep watershed of Valais Alps (Switzerland): Dendrogeomorphic event reconstruction and identification of triggers, Geomorphology, 116, 107114, 2010.

Tobler, D., Kull, I., Jacquemart, M., and Haehlen, N.: Hazard Management in a Debris Flow Affected Area: Case Study from Spreitgraben, Switzerland, Landslide Science for a Safer Geoenvironment, 3, 25-30, https://doi.org/10.1007/978-3-319-04996-0_5, 2014.

Vallance, J. W. and Scott, K. M.: The Osceola Mudflow from Mount Rainier: Sedimentology and hazard implications of a huge clayrich debris flow, Geol. Soc. Am. Bull., 109, 143-163, 1997.

Vandine, D. F. and Bovis, M.: History and goals of Canadian debrisflow research, a review, Nat. Hazards, 26, 69-82, 2002.

Wang, G., Sassa, K., and Fukuoka, H.: Downslope volume enlargement of a debris slide-debris flow in the 1999 Hiroshima, Japan, rainstorm, Eng. Geol., 69, 309-330, 2003. 